\title{
EFFECT OF PROBIOTICS SUPPLEMENTATION ON GROWTH AND PHYSIOLOGICAL PERFORMANCE OF MAGHATIR CAMEL-CALVES
}

Hussein, A. F.

Biotechnology Department, Faculty of Science (Al-Khumrah), Taif University; KSA, * Animal Production Department, Faculty of Agriculture, Ain Shams University Cairo, Egypt

\section{SUMMARY}

This study was conducted to investigate the effect of probiotics inclusion on growth traits, hematological profile and thyroid hormones $\left(T_{3}\right.$ and $\left.T_{4}\right)$ concentration at monthly intervals for six months period. 22 early weaned camel-calves of Maghatir breed (12 males and 10 females) aged 6-7 months and weighing $186.6 \pm 0.3$ and $173.2 \pm 0.0 .5 \mathrm{~kg}$ for males and females, respectively were used. Calves were allotted into two main groups according to their gender and each gender was assigned into two equal groups had approximately similar body weight. The first group fed concentrate feed mixtures (CFM) without probiotics and served as control group $(C)$, whereas, the second group fed CFM plus $20 \mathrm{~g} / \mathrm{h} / \mathrm{d}$ of probiotics and served as treated group $(P)$. Live body weight $(B W)$ and hematological parameters (hemoglobin concentration, Hb; packed cell volume, $P C V$; erythrocyte count, RBC's; and total leukocytes count, WBC's) were determined monthly. In addition derived erythrocyte indices (mean corpuscular volume, $M C V$, fl; mean corpuscular hemoglobin, $M C H$, pg and mean corpuscular hemoglobin concentration, MCHC \%) were calculated in addition to plasma thyroid hormones concentration.

Results indicated that males of $(P)$ group gained more body weight $(+5.39 \%)$ compared with the corresponding females' one. Probiotics supplementation improved ADG for males (18.5\%) and females $(4.9 \%)$, respectively than control groups. Porbiotics supplementation had no effect $(P>0.05)$ on plasma $T_{3}$ and $T_{4}$ concentrations in both genders. Hb, $P C V, R B C$ 's and $W B C$ 's values significantly $(P<0.05)$ affected in both gender calves supplemented probiotics compared with control calves.

Gender had significant effects on body weight, hematological parameters and $T_{3}$ and $T_{4}$ where females had higher values $(P<0.05)$ of $\mathrm{Hb}, P C V$ and $R B C$ 's count, while male calves had higher $(P<0.05)$ values of $B W$, $W B C$ 's count, $T_{4}$ and $T_{3}$ levels than females. Daily gain of control groups showed that male calves had higher $(P<0.01)$ daily gain than the female calves. In addition, plasma $T_{3}$ concentrations increased $(P<0.001)$ over time in both genders and tended to be more related to body weight gain, while $T_{4}$ behaved the opposite trend.

It could be concluded that probiotics supplementation $(20 \mathrm{~g} / \mathrm{h} / \mathrm{d})$ in ration of post-weaning camel calves improving weight gain and physiological status.

\section{Keywords: camel-calves, probiotics, body weight, hematological traits, thyroid hormones}

\section{INTRODUCTION}

One of the best feed additives for ruminant rations is the probiotics or direct fed microbial (DFM). DFMare viable microbial cultures and enzyme preparations that improve intestine microbial balance (Fuller, 1989). Manipulating rumen digestion system through the addition of DFM and a fibrolytic enzymes to ruminant rations enhance cellulose digestion and improve the animal performance Fadel and Abusamra (2007; Musa et al. (2009) and Mandour et al. (2009).

Live yeast supplements release essential enzymes, vitamins and aminoacids during digestion, which have apositive effect on the performance of ruminants (Newbold, 1995) in general and on average daily gain and feed efficiency in particular (El-Ashry et al., 2003;Salama et al., 2005 and Fadel and Abusamra, 2007).

Aro and Akinmoegun (2012)and Aro et al. (2013) reported that hematological parameters are used in routine screening for the health and physiological status of livestock. Mean values of corpuscular volume; corpuscular hemoglobin and corpuscular hemoglobin concentration have a considerable importance in determination of health status of flock (Saddiqi et al., 2011).

Hematological parameters are influenced by many factors like genotype, age, gender, seasonal variations, lactation, pregnancy, health and nutrition status (Aengwanich,2002; Al-Shami, 2007; Gupta et al., 2007, Mohammed et al., 2007 and Mohri et al., 2007).During calves' weaning time, total leukocytes count increased significantly as observed by Mohri et al. (2007).

Huska et al. (2002) and Jukna et al. (2003) reported in their studies that calves received probiotic had a good health status as indicated by hematological parameters.

Thyroxine and tri-iodothyronine hormones are involved in the regulation of metabolic process at body tissues, growth and development, reproduction, and adaptation in farm animals (Kahl and Bitman, 1983 and Todini, 2007).

The objective of this study was to evaluate the effect of probiotics supplementation on growth indices, hematological parameters and thyroid hormones concentrations in both male and female Maghatir camel-calves during post-weaning period. 


\section{MATERIALS AND METHODS}

\section{Animals and experimental procedure:}

A total of 22 early weaned camel-calves of Maghatir breed (12 males and 10 females) were used in this study. Calves had age of 6-7 months and weighing $186.6 \pm 0.3$ and $173.2 \pm 0.5 \mathrm{~kg}$ for males and females, respectively. Calves were divided into two equal groups/gender. The first group in each gender served as control and fed concentrates feed mixture (CFM) without probiotics, while the second group was fed CFM containing probiotics as growth promoter and housed in 4 separated pens. The study lasted six months period. CFM was offered once a day in the morning (at 08:00 am) and was adjusted monthly to meet the changes of body weight as reported by Kearl (1982). All the calves fed clover hay $(\mathrm{CH})$ ad libitum as roughage throughout the experiment. The CFM consisted of $67 \%$ whole yellow corn, $13 \%$ wheat bran, $15 \%$ soybean meal, $1.2 \%$ premix, $0.8 \%$ common salt and $3 \%$ limestone. Fresh water was offered once daily. All calves were provided free-choice access to a salt-based trace mineral mix that contained $12.0 \% \mathrm{Ca}, 9.0 \% \mathrm{~B}, 9.0 \%$ $\mathrm{Na}, 0.30 \% \mathrm{Zn}, 0.15 \% \mathrm{Cu}, 0.05 \% \mathrm{Mn}, 0.02 \% \mathrm{I}$, $0.005 \% \mathrm{Co}$, and $0.004 \% \mathrm{Se}$; in a blocks form $3 \mathrm{~kg}$ each).

The chemical composition of $\mathrm{CFM}$ and $\mathrm{CH}$ (on DM basis \%) are presented in Table (1). Proximate analyses were determined by the standard AOAC (1995), while nitrogen-free extract (NFE) was determined by the calculated difference.

Table 1. The chemical composition (on DM basis, \%) of concentrate feed mixture (CFM) and clover hay (CH)

\begin{tabular}{llllllll}
\hline Item & DM & OM & CP & CF & EE & Ash & NEF \\
\hline CFM & 90.43 & 92.79 & 16.97 & 10.61 & 4.37 & 8.24 & 61.21 \\
CH & 89.96 & 90.00 & 13.76 & 36.20 & 1.28 & 10.03 & 38.76 \\
\hline
\end{tabular}

"CFM; concentrate feed mixture contained; $67 \%$ whole yellow, $13 \%$ wheat bran, $15 \%$ soybean meal, $1.2 \%$ premix, $0.8 \%$ common salt and $3 \%$ limestone.

The dried commercial probiotics (BiyoteksinTM L, Novartison) was added in a powder form at a level of $20 \mathrm{~g} / \mathrm{h} / \mathrm{d}$ (Abdel-Fattah et al., 2011). According to the supplier each $\mathrm{kg}$ probiotics contains variety of microbial species; with lactose as a carrier compound plus numerous of minerals, amino acids and vitamins. Calves were weighed at monthly using an aviary weighing-machine to the nearest 100 grams (at 08:00 a.m.).The average daily weight gain (ADG), total gain (TG) and growth rate (GR) was calculated as follows:

Total weight gain, $\mathrm{kg}=$ final weight - initial weight Average daily gain, $\mathrm{g}=$ (final weight, $\mathrm{g}-$ initial weight, g) / experimental period in days Growth rate, $\%=$ (final weight, $\mathrm{kg}$ - initial weight, $\mathrm{kg}$ ) / initial weight, $\mathrm{kg}^{*} 100$

\section{Blood sampling and analyses:}

Blood samples were collected from the jugular vein of the calves. Monthly, approximately $10 \mathrm{ml}$ of blood was taken of each animal at early morning (just before feeding and drinking) intest tubes containing Lithium heparin as anticoagulant. Hemoglobin concentration $(\mathrm{Hb}, \mathrm{g} / \mathrm{dl})$ was determined in blood according to Drabkin and Austin (1932), while packed cells volume (PCV \%) was estimated according to Chyrel et al. (1992). Erythrocytes count $\left(\mathrm{RBC}\right.$ 's $\times 10^{6}$ cells $\left./ \mu \mathrm{l}\right)$ was made by diluting whole blood, 1:200 in physiological saline solution, while total leukocytes (WBC's $\times 10^{3}$ cells/ $\mu \mathrm{l}$ ) was count in blood diluted 1:50 according to Chyrelet al. (1992).Erythrocyte indices in terms of the mean corpuscular volume (MCV,fl), mean corpuscular hemoglobin ( $\mathrm{MCH}, \mathrm{pg}$ ) and mean corpuscular hemoglobin concentration (MCHC, \%) were calculated according to Chyrel et al. (1992) as follows:
$\mathrm{MCV}, \mathrm{Fl}=\left(\mathrm{Ht}, \% / \mathrm{RBC}\right.$ 's, $\left.\mathrm{x} 10^{6} / \mathrm{mm}^{3}\right) * 100$

$\mathrm{MCH}, \mathrm{pg}=\left(\mathrm{Hb}, \mathrm{g} / \mathrm{dl} / \mathrm{RBC}\right.$ 's, $\left.\times 10^{6} / \mathrm{mm}^{3}\right) * 10$

$\mathrm{MCHC}, \%=(\mathrm{Hb}, \mathrm{g} / \mathrm{dl} / \mathrm{Ht}, \%) * 100$

\section{Hormonal assays:}

Plasma concentrations of $\mathrm{T}_{3}$ and $\mathrm{T}_{4}$ were determined by using Dia Sorin CLIA kits (Stradaper Cresentino-13040 Saluggia (Vercelli) - Italy) with the LIAISON analyzer. The validation for these hormones assays assessed the limits of detection, precision of standard curve following sample dilution and intra-and inter-assay coefficient of variation of the results.

\section{Statistical analysis:}

Statistical analysis was conducted using the general linear model (GLM) procedures of SAS (2003). A repeated measurement model was used. Distributed Duncan's tests (1955) were used to compare the treatment means. Dead calves were subtracted form the total number (22) and statistical analysis was done on raw data of 20 camel-calves for six months period.

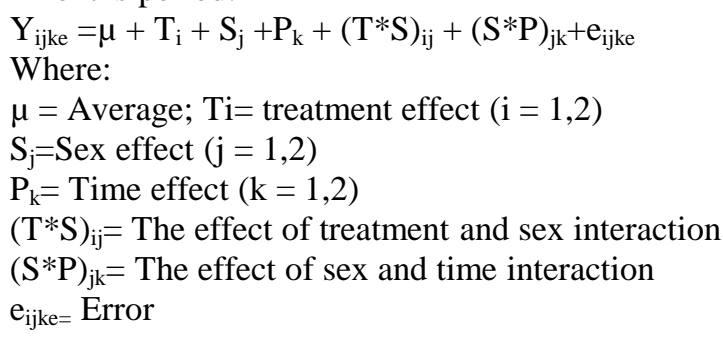

\section{RESULTS AND DISCUSSION}

\section{Productive performance:} Clinical observations: 
Severe diarrhea was reported in two males and died at the end of the second month of study. The main cause of this death was diarrhea. Etiologically, the disease was caused by mixed infection with numerous microbes, notably Salmonella spp. and $E$. coli (Abbas et al., 1992a and Bengoumi et al., 1998).The mortality rate reported in this study $(9.10 \%)$ is within the expected range and is comparable to the rate recorded previously by Abbas et al.(1992a).

\section{Effect of treatment \\ Body weight changes:}

\section{Effect of probiotics}

Results in Table (2) indicated that BW of the treated calves was higher in both genders throughout the study. On the other hand, ADG, TG and GR was more distinctive in treated calves compared with control.The present results are in accordance with the findings of Ismaiel et al. (2010) and Adel and ELMetwaly (2012) who reported that final weight gain; ADG and TG were significantly higher in treated supplemented groups than control group of camel calves. Similar trends were observed on Najdi lambs (Hussein, 2014) and Nubian goats (Fadel and Abusamra, 2007). They attributed the improvement in daily gain as a result of adding Saccharomyces cerevisiae and its effect on microbial efficiency and organic matter, crude protein and crude fiber digestibility's. These results are supported by the results of Gado et al. (2009) and Adel and El Metwaly (2012) who reported that dry matter and organic matter digestibility was significantly lower
$(\mathrm{P}<0.05)$ in dairy cows fed control ration than rations with ZADO supplementation.

On the other hand, this is in disagreement with the findings of Titi et al. (2008) who reported that yeast supplementation had no effect on growth rate in lambs and kids. Whitley et al.(2009) found that growth performance of goats remained unaltered with probiotics supplementation, except in one growth trial in which weight gain and feed conversion ratio was higher in probiotics supplemented group compared with the control.

\section{Effect of gender}

Results in Table (2) indicated that gender had a significant effect $(\mathrm{P}<0.05)$ where male calves had the heavier BW than females by about $8.74 \%$. Similar results were reported by Abbas et al. (2010); Saddiqi et al. (2011); Abdel-Fattah et al. (2013) and Wielgosz-Groth et al. (2015).

Abbas et al. (2010) demonstrated that gender had significant effect on BW with advance of age in camel's calves. This may be due to the secretion of sex testosterone, which enhances growth in males. As shown in Table (2) and Fig.(1), Male-calves had higher $(\mathrm{P}<0.01)$ final body weights than femalecalves.In the present study.

Kadim et al. (2008) and Asadzadeh et al. (2010) found that sex has no effect on live weights of camel at early ages of one humped camels but at the later ages, males had significantly heavier live body weights than females. Asadzadeh et al. (2010) reported that live weight for the fattened males was higher (376.7 \pm 18.6$)$ compared with fattened females $(342.0 \pm 18.6) \mathrm{kg}$ at 21 months of age.

Table 2. Means \pm SE of body weight, average daily gain, total gain and growth rate of weaned camel-calves fed diet with or without probiotics during post-weaning period

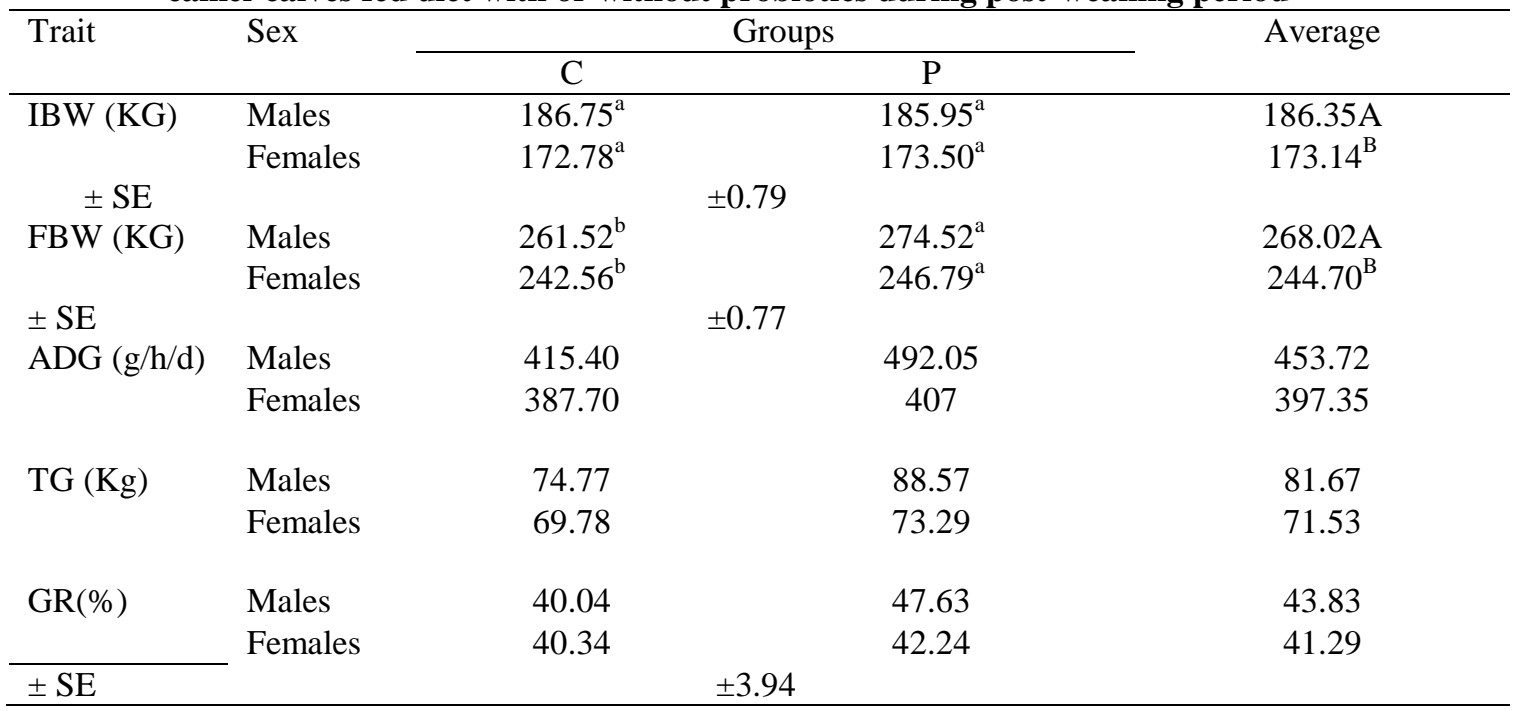

IBW= initial body weight; FBW= final body weight; $\mathrm{ADG}=$ average daily gain; $\mathrm{TG}=$ total gain; $\mathrm{GR}=$ growth rate; ${ }^{\mathrm{a}},{ }^{\mathrm{b}}$ in the same row bearing significant different at $(\mathrm{P}<0.05)$; ${ }^{\mathrm{A}},{ }^{\mathrm{B}}$ in the same column bearing significant different at $(\mathrm{P}<0.01) ; \mathrm{C}=$ control group; $\mathrm{P}=$ probiotics group 


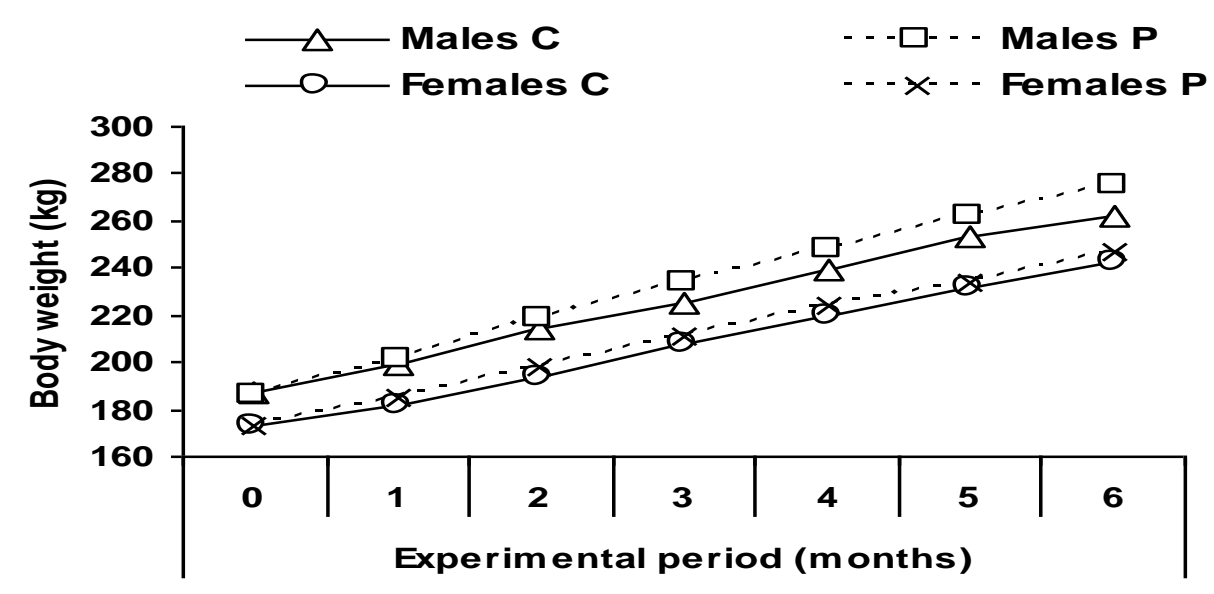

Fig.(1) Effect of probiotics supplementation on body weight of male and female camel-calves during post-weaning period

\section{Physiological performance: \\ 2.1. Hematological responses Effect of probiotics}

Supplementing rations with probiotics indicated that $\mathrm{Hb}, \mathrm{PCV}, \mathrm{RBC}$ 's and WBC's values were higher $(\mathrm{P}<0.05)$ in the treated group compared with the control (Table 3). These findings agree with the findings of Milewski and Sobiech (2009) who reported that natural feed additives increased $(\mathrm{P}<0.05) \mathrm{Hb}, \mathrm{PCV}, \mathrm{RBC}$ 's, WBC's and MCVas compared with control groupof ewes.

Contrariwise, Sarker et al. (2010) reported that there were no significant differences $(\mathrm{P}>0.05)$ in blood Hb,RBC's and WBC's among the feed additive groups compared to control group during postweaning period of the Korean native calves (Hanwoo), Hanwoo is a pure breed maintained by the Korean national breeding system (Kee et al ., 2008) and the phylogenetic tree based mitochondrial DNA sequence homology shows that Hanwoo belongs to the humpless Taurine species, Bos Taurus (Kikkawa et al., 2003). Ali-Arab et al. (2014) reported that lambs received 0.5 and/or $1.0 \mathrm{~g}$ Bioplus $/ \mathrm{kg}$ of feed caused a significant $(\mathrm{P}<0.05)$ decrease in the values of $\mathrm{Hb}, \mathrm{PCV}$ and RBC's. Riddell et al. (2010) reported no differences were observed in packed cell volume between control and treated Holstein calves with probiotics. Adams et al. (2008) also found no variation between probiotic treated calves and their control counterparts in overall hematocrit. Dimova et al. (2013) reported that there was no significant differences $(\mathrm{P}>0.05)$ in hematological parameters between probiotic treated group $(12 \mathrm{~g} / \mathrm{h} / \mathrm{d})$ and control one at the beginning and the end of the study.

\section{Effect of Gender}

The obtained results indicated that $\mathrm{Hb}, \mathrm{PCV}$ and RBC's values were higher in females than males throughout the study (Figures2, 3 and 4) but male calves hadthe higher value of WBC's (Fig.5) than females. In accordance, Tibbo et al. (2004)on goats; Saddiqi et al. (2011) on Kajli lambs; Opara et al.
(2010) on West African Dwarf (WAD) goats and Abdel-Fattah et al. (2013) on Barki lambs reported that blood values of $\mathrm{Hb}, \mathrm{PCV}, \mathrm{RBC}$ 's were higher $(\mathrm{P}<0.01)$ in females than males.

This observation is in contrast with values obtained for Red Sokoto goats in Nigeria (Tambuwal et al, 2002) in which male animals have higher values than females. Hussein et al. (2012) reported that no significant effect of gender on $\mathrm{Hb}, \mathrm{PCV}$, RBC's, MCHC and WBC's, while MCV and $\mathrm{MCH}$ were higher $(\mathrm{P}<0.05)$ in female compared to male camels for Majahim and Maghatir dromedary camels. Likwise, Olayemi et al. (2006) on Gudali and Kuri cattles, Awolaja et al. (1997) on Keteku cattle reported that there was no gender difference in the RBC's values.

The obtained results revealed that, in both genders, hematological traits improved linearly with weight gain but calves supplemented probiotics has the better improvement compared with control calves $(8.5,8.6,4.02$ and $4.30 v s .4 .5,3.1,0.82$ and $0.54 \%)$ for males. The corresponding values for females recorded $(10.61,6.62,6.4$, and 6.63 vs. 5.06, 1.42, 2.3 and $-0.34 \%$ ) for $\mathrm{Hb}, \mathrm{PCV}, \mathrm{RBC}$ 's and WBC's, respectively. In agreement, Thomas et al. (1994) and Chang'a et al. (2012) reported that there was a significant correlation between blood $\mathrm{Hb}$ level and BW gain in calves.

\subsection{Erythrocyte indices:}

Results in Table (4) indicated that probiotics caused a significant increase in MCHC (42.13\%) compared with control group $(40.72 \%)$, but $\mathrm{MCH}$ values tended to be decreased. Supplementing rations with the probiotics had no effect on MCV values of female calves. On the other hand, probiotics supplementation had no significant effect on MCV, $\mathrm{MCH}$ and MCHC values of male calves. Mandour et al. (2009) reported that probiotics supplementation caused a significant decrease of $\mathrm{MCH}$ in weaned Najdi lambs and significant increase on MCHC in weaned Awassi lambs relativeto control groups. 
Ali-Arab et al. (2014) reported that lambs received $0.5 \mathrm{and} / \mathrm{or} 1.0 \mathrm{~g}$ Bioplus $/ \mathrm{kg}$ of feed caused an $(\mathrm{P}<0.05)$ in $\mathrm{MCV}$ and $\mathrm{MCH}$ levels.

The present results indicated that, no interaction between gender and treatment on MCV and $\mathrm{MCH}$.

Unlike, Sarker et al. (2010) found that, there were no significant differences $(\mathrm{P}>0.05)$ in $\mathrm{MCV}, \mathrm{MCH}$, MCHC among the feed additive groups of Hanwoo calves. Kunavue and Lien (2012) reported that folic acid and probiotics supplementation with diets did not show any significant difference compared with the control group of pigs.
Concerning the effect of sex, results in Table (4) indicated that the averages of MCV and MCHC were higher by 3.8 and $2.0 \%$, respectively in females than males.MeanwhileMCH was higher by $2.0 \%$ in males than females. Therefore, it could be explain the increase of $\mathrm{MCH}$ level in males was attributed to the decrease in MCV value. Mirzadeh et al. (2010) reported that $\mathrm{MCH}$ were significantly $(\mathrm{P}<0.05)$ higher in males than females of Iranian cattle. Finally, AL-Busadah. (2007) reported that no signif icant effect due to breed or sex on erythrocytic indices and leukocytic series of Majahim, Maghatir and Awarike camel breeds in Saudi Arabia.

Table 3. Means $\pm \mathrm{SE}$ of blood hemoglobin, packed cell volume, erythrocytes and leukocytes counts of weaned camel-calves fed diet with or without probiotics during post-weaning period

\begin{tabular}{|c|c|c|c|c|c|c|c|c|c|}
\hline \multirow[t]{2}{*}{ Trait } & \multirow[t]{2}{*}{ Sex } & \multicolumn{2}{|c|}{ Initial } & \multirow[t]{2}{*}{ Average } & \multicolumn{2}{|c|}{ Final } & \multirow[t]{2}{*}{ Average } & \multicolumn{2}{|c|}{ Change \% } \\
\hline & & $\mathrm{C}$ & $\mathbf{P}$ & & $\mathbf{C}$ & $\mathbf{P}$ & & $\mathbf{C}$ & $\mathbf{P}$ \\
\hline \multirow{3}{*}{$\begin{array}{l}\text { Hb } \\
(\mathrm{g} / \mathrm{dl})\end{array}$} & Males & $10.23^{b}$ & $10.23^{b}$ & $10.23^{\mathrm{B}}$ & $10.69^{b}$ & $11.10^{b}$ & $10.90^{\mathrm{B}}$ & 4.5 & 8.5 \\
\hline & Females & $11.07^{\mathrm{a}}$ & $11.03^{\mathrm{a}}$ & $11.05^{\mathrm{A}}$ & $11.63^{\mathrm{a}}$ & $12.20^{\mathrm{a}}$ & $11.92^{\mathrm{A}}$ & 5.06 & 10.61 \\
\hline & $\pm \mathrm{SE}$ & \multicolumn{8}{|c|}{ \pm 0.10} \\
\hline \multirow{3}{*}{$\begin{array}{l}\text { PCV } \\
(\%)\end{array}$} & Males & $26.0^{\mathrm{b}}$ & $25.6^{\mathrm{b}}$ & $25.8^{\mathrm{B}}$ & $26.8^{\mathrm{b}}$ & $27.8^{\mathrm{b}}$ & $27.3^{\mathrm{B}}$ & 3.1 & 8.6 \\
\hline & Females & $28.2^{\mathrm{a}}$ & $27.2^{\mathrm{a}}$ & $27.7^{\mathrm{A}}$ & $28.6^{\mathrm{a}}$ & $29.0^{\mathrm{a}}$ & $28.8^{\mathrm{A}}$ & 1.42 & 6.62 \\
\hline & $\pm \mathrm{SE}$ & \multicolumn{8}{|c|}{ \pm 0.40} \\
\hline \multirow[t]{3}{*}{ RBC's } & Males & $7.30^{\mathrm{b}}$ & $7.21^{\mathrm{b}}$ & $7.24^{B}$ & $7.36^{\mathrm{b}}$ & $7.50^{\mathrm{b}}$ & $7.32^{\mathrm{B}}$ & 0.82 & 4.02 \\
\hline & Females & $7.64^{\mathrm{a}}$ & $7.65^{\mathrm{a}}$ & $7.44^{\mathrm{A}}$ & $7.82^{\mathrm{a}}$ & $8.14^{\mathrm{a}}$ & $7.62^{\mathrm{A}}$ & 2.3 & 6.40 \\
\hline & $\pm \mathrm{SE}$ & \multicolumn{8}{|c|}{ \pm 0.09} \\
\hline \multirow[t]{3}{*}{ WBC's } & Males & $9.30^{\mathrm{a}}$ & $9.32^{\mathrm{a}}$ & $9.31^{\mathrm{A}}$ & $9.35^{\mathrm{a}}$ & $9.72^{\mathrm{a}}$ & $9.54^{\mathrm{A}}$ & 0.54 & 4.30 \\
\hline & Females & $8.70^{\mathrm{b}}$ & $8.60^{\mathrm{b}}$ & $8.65^{B}$ & $8.67^{\mathrm{b}}$ & $9.17^{\mathrm{b}}$ & $8.92^{B}$ & - 0.34 & 6.63 \\
\hline & $\pm \mathrm{SE}$ & \multicolumn{8}{|c|}{ \pm 0.10} \\
\hline
\end{tabular}

$\overline{\mathrm{C}}=$ control group $\mathrm{P}=$ probiotics group; $\mathrm{Hb}=$ hemoglobin, $\mathrm{PCV}=$ packed cell volume; $\mathrm{RBC}$ 's = erythrocytes count $\left(\mathrm{x} 10^{6}\right.$ cells $/ \mu 1) ; \mathrm{WBC}$ 's $=$ total leucocyte count $\left(\mathrm{x} 10^{3}\right.$ cells $\left./ \mu 1\right) ; \quad{ }^{\mathrm{a}},{ }^{\mathrm{b}}$ in the same row bearing significant different at $(\mathrm{P}<0.05)$; ${ }^{\mathrm{A}, \mathrm{B}}$ in the same column bearing significant different at $(\mathrm{P}<0.01)$

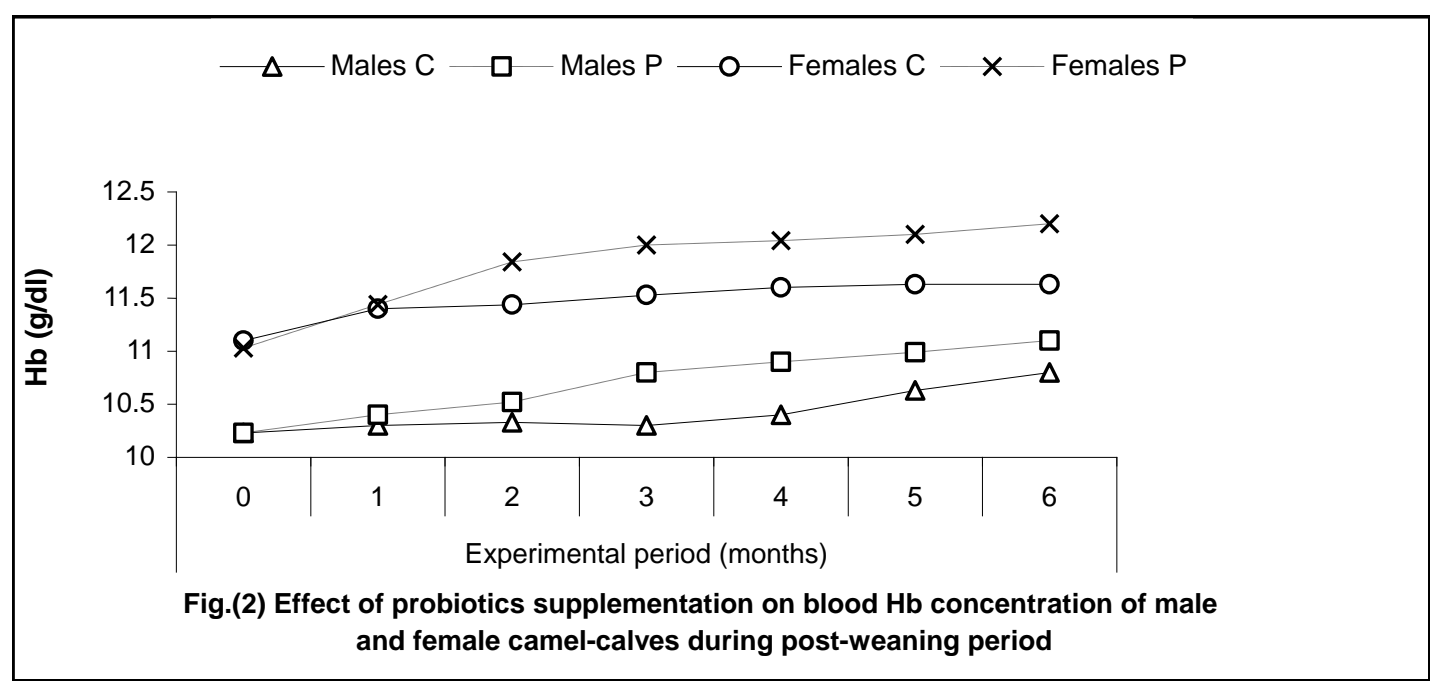



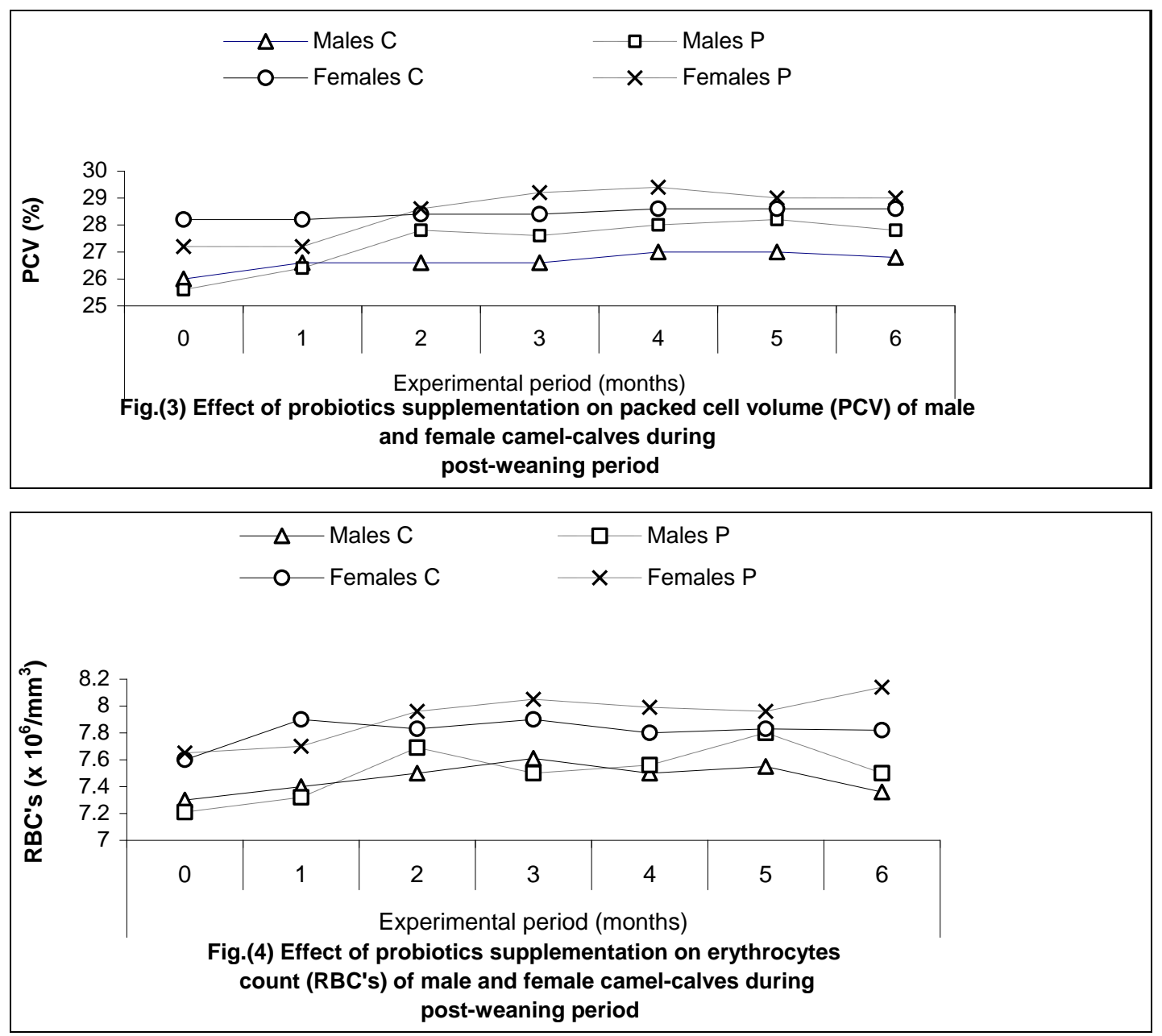

Table 4. Means \pm SE of derived erythrocyte indices (MCV, MCH and MCHC) of weaned camel-calves fed diet with or without probiotics during post-weaning period

\begin{tabular}{|c|c|c|c|c|c|c|c|}
\hline \multirow[t]{2}{*}{ Trait } & \multirow[t]{2}{*}{ Sex } & \multicolumn{2}{|c|}{ Initial } & \multirow[t]{2}{*}{ Average } & \multicolumn{2}{|c|}{ Final } & \multirow[t]{2}{*}{ Average } \\
\hline & & $\mathbf{C}$ & $\mathbf{P}$ & & $\mathrm{C}$ & $\mathbf{P}$ & \\
\hline \multirow{3}{*}{$\begin{array}{l}\text { MCV } \\
\text { (fl)) }\end{array}$} & Males & $14.06^{\mathrm{a}}$ & $14.19^{\mathrm{a}}$ & $14.13^{B}$ & $14.68^{\mathrm{a}}$ & $14.83^{\mathrm{a}}$ & $14.92^{B}$ \\
\hline & Females & $14.58^{\mathrm{a}}$ & $14.42^{\mathrm{a}}$ & $14.50^{\mathrm{A}}$ & $14.89^{\mathrm{a}}$ & $15.10^{\mathrm{a}}$ & $15.64^{\mathrm{A}}$ \\
\hline & $\pm \mathrm{SE}$ & \multicolumn{6}{|c|}{ \pm 0.20} \\
\hline \multirow{3}{*}{$\begin{array}{l}\mathrm{MCH} \\
(\mathrm{pg})\end{array}$} & Males & $25.4^{\mathrm{a}}$ & $24.01^{\mathrm{b}}$ & $25.2^{\mathrm{A}}$ & $24.82^{\mathrm{a}}$ & $25.04^{\mathrm{a}}$ & $25.02^{\mathrm{A}}$ \\
\hline & Females & $25.48^{\mathrm{a}}$ & $24.66^{\mathrm{b}}$ & $25.07^{B}$ & $24.58^{\mathrm{a}}$ & $23.79^{b}$ & $24.19^{B}$ \\
\hline & $\pm \mathrm{SE}$ & \multicolumn{6}{|c|}{$\pm \mathbf{0 . 5 0}$} \\
\hline \multirow{3}{*}{$\begin{array}{l}\mathrm{MCHC} \\
(\%)\end{array}$} & Males & $39.41^{\mathrm{a}}$ & $40.15^{\mathrm{a}}$ & $39.78^{B}$ & $40.38^{\mathrm{a}}$ & $40.03^{\mathrm{a}}$ & $40.07^{B}$ \\
\hline & Females & $39.33^{\mathrm{b}}$ & $40.74^{\mathrm{a}}$ & $40.03^{A}$ & $40.72^{b}$ & $42.13^{\mathrm{a}}$ & $41.42^{\mathrm{A}}$ \\
\hline & $\pm \mathrm{SE}$ & \multicolumn{6}{|c|}{ \pm 0.80} \\
\hline
\end{tabular}

$\mathrm{C}=$ control group $\mathrm{P}=$ probiotics group; $\mathrm{MCV}=$ mean corpuscular volume, $\mathrm{MCH}=$ mean corpuscular hemoglobin, $\mathrm{MCHC}=$ mean corpuscular hemoglobin concentration; ${ }^{\mathrm{a}}, \mathrm{b}$ in the same row bearing significant different at $(\mathrm{P}<0.05)$; ${ }^{A},{ }^{B}$ in the same column bearing significant different at $(\mathrm{P}<0.01)$

\subsection{Thyroid hormones:}

Regarding the effect of probiotics, as shown in Table 5 results indicated that there were no significant effects on plasma concentrations of $\mathrm{T}_{4}$ or $\mathrm{T}_{3}$ among treated and control calves in both genders. As shown in Figs. 6 and 7, the determined thyroid hormones $\left(\mathrm{T}_{3}\right.$ and $\left.\mathrm{T}_{4}\right)$ concentrations did not differ and remained almost the same from initial till the third month of study in both control and treated groups of each gender, after that plasma concentration of $\mathrm{T}_{3}$ began to be increased $(\mathrm{P}<0.05)$ from the $4^{\text {th }}$ month till the end of the study, the opposite trend was observed for $\mathrm{T}_{4}$ concentration in all calves. This result may be due to that $\mathrm{T}_{4}$ 
transformed to $\mathrm{T}_{3}$ in tissues before it becomes biologically active (Boonnamsiri et $a l, 1979)$.Therefore, in both genders, the highest $\mathrm{T}_{3}$ concentration was recorded at the end of study while the lowest $\mathrm{T}_{4}$ concentration was recorded at the end of study, In addition, there was no significant differences between control and treated groups along the study in both genders.

Table 5. Means $\pm S E$ of thyroid hormones (tri-iodothyronine, $T_{3}$ and thyroxine $T_{4}$ ) concentrations of weaned camel-calves fed diet with or without probiotics during post-weaning period

\begin{tabular}{|c|c|c|c|c|c|c|c|}
\hline \multirow[t]{2}{*}{ Trait } & \multirow[t]{2}{*}{ Sex } & \multicolumn{2}{|c|}{ Initial } & \multirow[t]{2}{*}{ Average } & \multicolumn{2}{|c|}{ Final } & \multirow[t]{2}{*}{ Average } \\
\hline & & $\mathbf{C}$ & $\mathbf{P}$ & & C & $\mathbf{P}$ & \\
\hline \multirow{2}{*}{$\begin{array}{l}\mathrm{T}_{3} \\
(\mathrm{ng} / \mathrm{ml})\end{array}$} & Males & $2.65^{\mathrm{a}}$ & $2.67^{\mathrm{a}}$ & $2.70^{\mathrm{A}}$ & $3.39^{\mathrm{a}}$ & $3.42^{\mathrm{a}}$ & $3.40^{\mathrm{A}}$ \\
\hline & $\begin{array}{l}\text { Females } \\
\mathbf{\pm S E}\end{array}$ & \multicolumn{5}{|c|}{ \pm 0.01} & $2.77^{\mathrm{B}}$ \\
\hline $\begin{array}{l}\mathrm{T}_{4} \\
(\mu \mathrm{g} / \mathrm{dl})\end{array}$ & $\begin{array}{l}\text { Males } \\
\text { Females } \\
\mathbf{\pm S E}\end{array}$ & $\begin{array}{l}153.5^{\mathrm{a}} \\
149.3^{\mathrm{a}}\end{array}$ & $\begin{array}{l}153.7^{\mathrm{a}} \\
148.4^{\mathrm{a}}\end{array}$ & $\begin{array}{l}153.58^{\mathrm{A}} \\
148.87^{\mathrm{B}}\end{array}$ & $\begin{array}{l}140.7^{\mathrm{a}} \\
138.7^{\mathrm{a}}\end{array}$ & $\begin{array}{l}140.3^{\mathrm{a}} \\
138.3^{\mathrm{a}}\end{array}$ & $\begin{array}{l}140.52^{\mathrm{A}} \\
138.51^{\mathrm{B}}\end{array}$ \\
\hline
\end{tabular}

$\mathrm{C}=$ control group $\mathrm{P}=$ probiotics group; ${ }^{\mathrm{a}},{ }^{\mathrm{b}}$ in the same row bearing significant different at $(\mathrm{P}<0.05)$;

${ }^{\mathrm{A}},{ }^{\mathrm{B}}$ in the same column bearing significant different at $(\mathrm{P}<0.01)$

In accordance, Estell et al. (1993) found that no effect $(\mathrm{P}>0.10)$ of supplementing Se yeast on thyroid hormones levels of the calf during post-weaning. LeDividich and Seve (2000) observedthatlevels of $\mathrm{T}_{3}$ and $\mathrm{T}_{4}$ after weaning but measured a decline of those two hormones after a change in the diet. The present results show that no interaction between treatment and gender for plasma $\mathrm{T}_{3}$ and $\mathrm{T}_{4}$ levels.

Similarly, in rams and ewes subcutaneously implanted with trenbolone acetate (TBA), Kahl et al. (1992) found a decrease in plasma thyroxine and hepatic 5'-deiodinase activity. This enzyme, 5'deiodinase, converts thyroxine to $3,5,3^{\prime}$ - triiodothyronine, which was the metabolically active thyroid hormone. Donaldson et al. (1981) also noted a decrease in plasma thyroxine of growing withers implanted with $140 \mathrm{mg}$ of TBA. This might suggest a decrease in lipid metabolism and (or) turnover of lipid in the lambs implanted with TBA.

\section{Effect of gender}

Results presented in Table (5) indicated that male calves had slightly higher overall means of $T_{3}$ and $\mathrm{T}_{4}$ concentrations compared with females. This is in agreement with the findings of Kahl and Bitman. (1983) whofound that average concentrations of $\mathrm{T}_{4}$ and $\mathrm{T}_{3}$ were 53.3 and $1.21 \mathrm{ng} / \mathrm{ml}$ for males and 39.9 and $1.06 \mathrm{ng} / \mathrm{ml}$ for females in growing Holstein cattle.

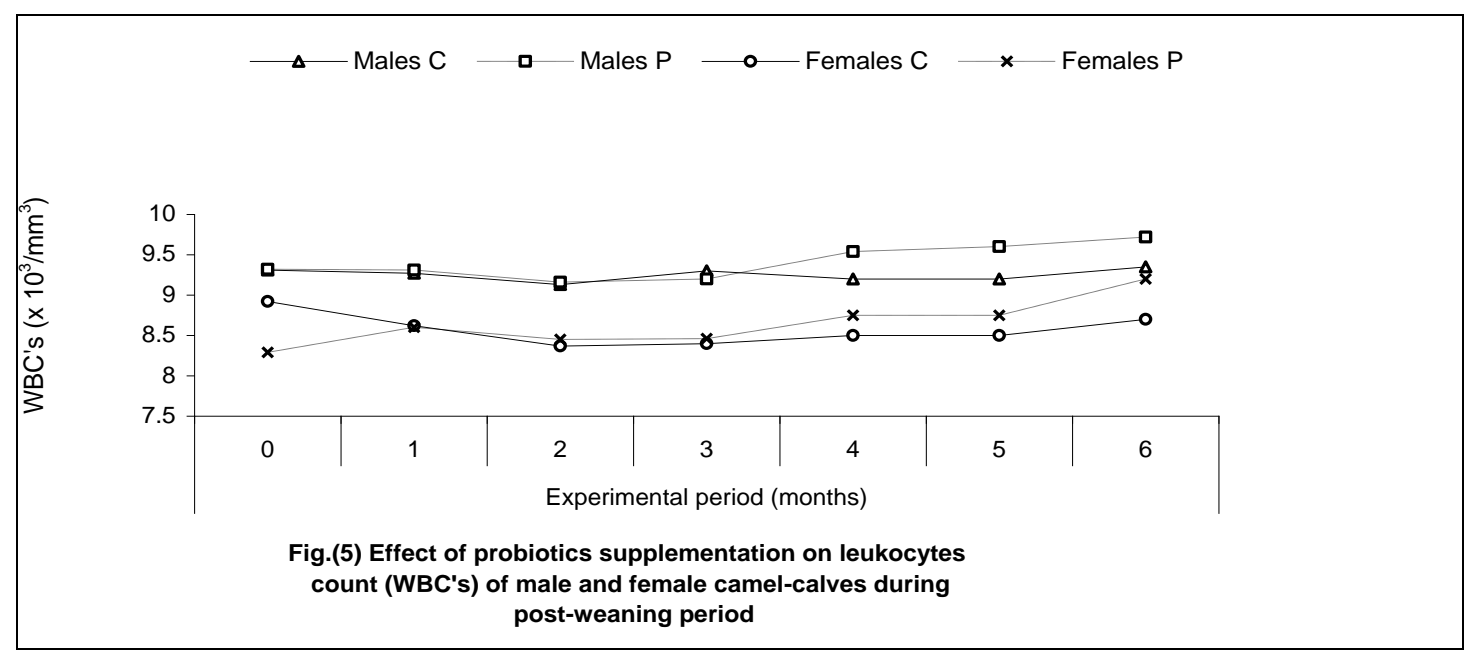



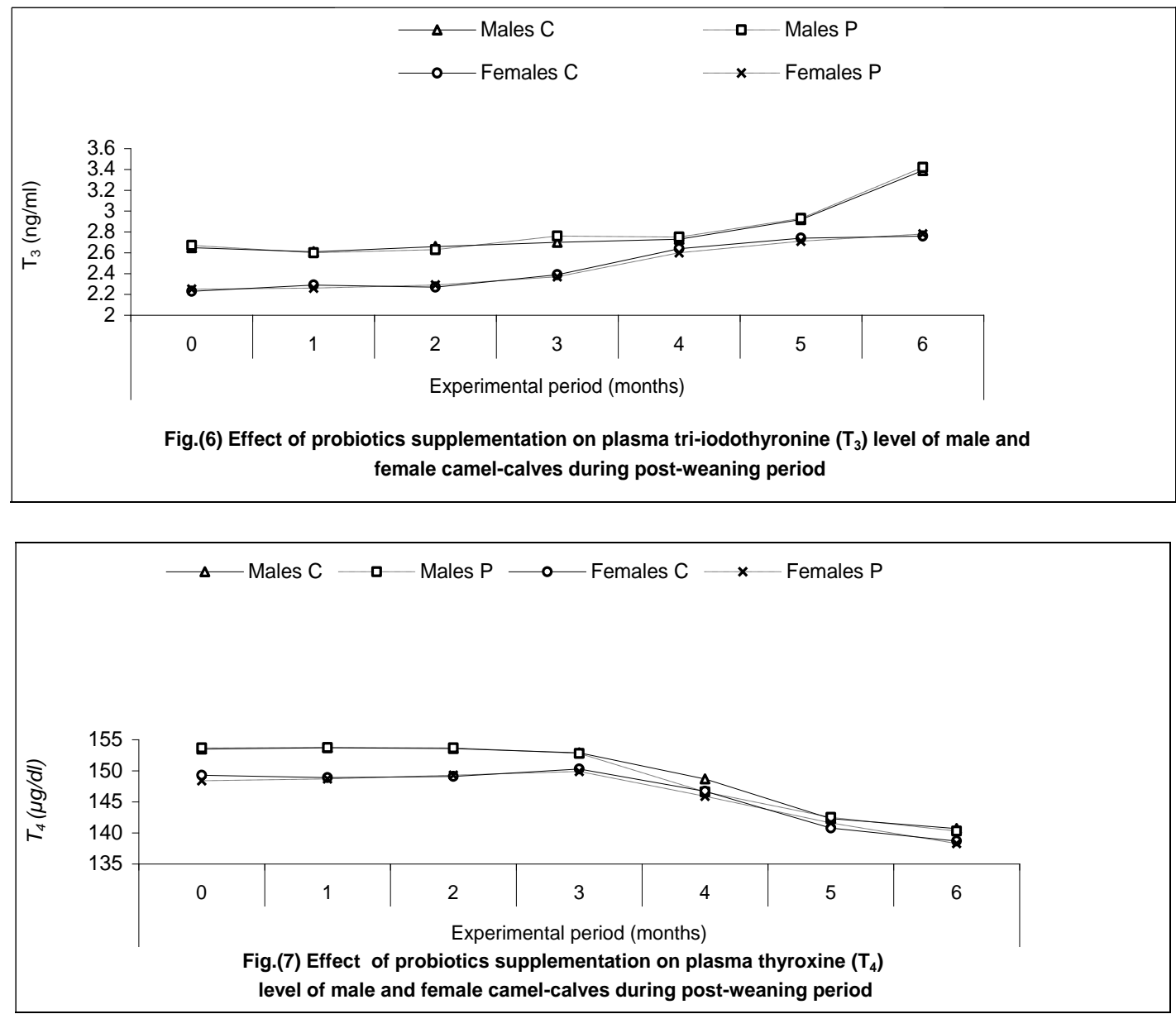

From the present results, the decrease of the circulating $\mathrm{T}_{3}$ and $\mathrm{T}_{4}$ levelsin female calves might explain their lower ADG than malesbeing 397.35 vs. $453.72 \mathrm{~g} / \mathrm{h} / \mathrm{d}$, respectively. As shown in Figs. (1) and (6), plasma $\mathrm{T}_{3}$ behaved the same trend for body weight in both genders along the study. Therefore, $\mathrm{T}_{3}$ may play the main role in metabolic rate. Sharma (1996) reported positive relationship between circulatory levels of thyroid hormones and body weight during growth in pre-pubertal and pubertal heifers.

Contrariwise, Eshratkhah et al. (2010 a) reported that no gender-dependent significant differences between two sexes in plasma thyroid hormones concentrations of Sarabi calves. Also, Todini (2007) on goats and Eshratkhah et al. (2010 b) on Moghani sheep observed the same trend.

\section{CONCLUSION}

It could be concluded that, the inclusion of probiotics in feeding camel-calves during postweaning period improved growth and physiological performance of both sexes.

\section{REFERENCES}

A.O.A.C.,1995.Official Methods of Analysis. Association of Analytical Chemists.Washington, D.C.

Abbas, B.; H. Agab,; G. E. Mohamed,; S. O. Yagoub, and K. Mustafa, 1992a.Clinical observations on field cases of diarrhoea in camel calves. Proceedings of the 5th Conference of General Federation of Arab Veterinarians held at Khartoum, Sudan. January, 21 - 24,(1992). pp. $128-137$.

Abbas, B.; N. Chabeuf, G. Saint Martin, P. Bonnet, B.E. Musa, 1992b. Camel pastoralism in Butana and northeastern Sudan, an interdisciplinary study. Nomadic Peoples, 31: 64-84.

Abbas, S.F., M. Abd-Allah, F.M.M.,Allam, and A.A. Aboul-Ella, 2010. Growth performance of Rahmani and Chios lambs weaned at different ages. Australian Journal of Basic and Applied Sciences, 4(7):1583-1589.

Abdel-Fattah, M.S.; A.L.S.Hashem; A.A. Azamel and H.A.M. Farghaly 2011.Effect of weaning stress, housing system and probiotics supplementation on cortisol, thyroid activity and productive performanoce of sucker calves. J. Rad.Res. Appl. Sci., 4(B):1291-1315.

Abdel-Fattah, M.S.; Y.M. Shaker; A.L.S. Hashem ;Ashgan M. Ellamei and Z. Hanan, Amer. 2013. Effect of weaning age on thermo-hematological and immunocompetence of Barki lambs in Siwa Oasis, Egypt. Global Veterinaria, 10(2):176-188

Adams MC, J. Luo, D. Rayward, S. King, R. Gib-son and GH.Moghaddam 2008.Selection of a novel direct-fed microbial to enhance weight gain in intensively reared calves. Anim. Feed Sci.,Tech.,145:41-52. 
Adel E.M. and H. EL-Metwaly, 2012.Effect of feed additive "Exogenous Enzymes" on growth performance of Maghraby Camels. Life Science Journal, 9 (4): 4830-4865.

Aengwanich, W., 2002. Effect of age on hematological values and blood profile of Holstein Friesian crossbred in Northeastern Thailand. Suranaree. J. Sci. Technol., 9:289-292.

AL-Busadah, K. 2007.Some biochemical and haematological indices in different breeds of camels in Saudi Arabia. Scientific Journal of KingFaisalUniversity,8(1):131-142.

Ali Arab, H.; A. Mashhadi-esmaeil, M. Rezaeian and M. Mohtasebi. 2014. Effects of Bacillus subtilis and Bacillus licheniformis-based probiotic on performance, hematological parameters and blood metabolites in lambs. International Journal of Food and Nutritional Sciences, 3, (4):8-15.

Al-Shami, S.A., 2007. Comparative study of hematological and blood biochemical components in milk-fed and conventionally-reared Hassawi breed calves. Sci. J. King Faisal Univ. Basic Applied Sci., 8:99-106.

Aro, S. O. and M. B. Akinmoegun, 2012. Haematology and red blood cell osmotic stability of pigs fed graded levels of fermented cassava peel based diets. Proc. $17^{\text {th }}$ Annual Conf. of Anim. Sci. Assoc. of Nigeria (ASAN) pp152-153.

Aro, S. O., F. F. Ogunwale and O. A., Falade, 2013. Blood viscosity of finisher cockere fed dietary inclusions of fermented cassava tuber wastes. Proc. of the $18^{\text {th }}$ Annual Conf. of Anim. Sci. Assoc. of Nig.pp 74-77.

Asadzadeh, N., H. Sadeghipanah, , M. H. Banabazi and A. Aghashahi, 2010. Effects of feedlot duration and sex on carcass characteristics of Kalkoohi dromedary camels.In Proc. 61st Annu. Mtg., European Association for Animal Production (EAAP),Heraklion, Greece, pp. 248.

Awolaja, O.A., R.E. Antia and A. Oyejide. 1997. Trace element level in plasma/serum and erythrocytes of Keteku and White Fulani cattle. Trop. Anim. Health Prod., 29:2-6.

Baranowski A, M. Gabryszuk, A. Jozwik, E. Bernatowicz and W. Chylinski, 2007. Fattening performance, slaughter indicators and meat chemical composition in lambs fed the diet supplemented with linseed and mineral bioplex. Animal Science Papers and Reports, pp. 25: 3544.

Bengoumi, M.; J. Barrada,; M. Rochdi,; K. Hidane,; F. De Lafarge, and B. Faye, 1998.Physiopathology of diarrhoea in the camel calf in Morocco. Clinical signs and metabolic disturbances. Rev Elev. Med. Vet. Pays Trop., 51(4): pp. $277-281$.

Boonnamsiri, V., J.C.Kermode, and B.D. Thompson, 1979. Prolonged intravenous infusion iodocompounds in the rat: $\left(\mathrm{I}^{125}\right)$ thyroxine and $\left(\mathrm{I}^{125}\right)$ triiodothyronine metabolism and extrathyroidal conversion of thyroxine to triiodothyronine. J. Endoc., 83:235-243.
Chang'a, J.S., T. Loken, H. R. Mdegela and O. Rekson., 2012. Factors associated with body weight attainment in calves on smallholder dairy farms in Tanzania. Open Journal of Veterinary Medicine, (2):66-73.

Cheryl,A.Lotsperch-Steininger; E.AnneStieneMartin; M.D. John and A. Koepke, 1992. Clinical Hematology: Principles, Procedures and Correlations.J/B/Lippincott Company. Philadelphia.,USA.

Dimova, N.; M. Baltadjieva; V. Karabashev; S. Laleva; Y. Popova; P.Slavova; J.Krastanov and G. Kalaydjiev, 2013.Effect of supplementation of probiotic Zoovit in diets of calves of milk breed. Bulgarian J. Agric. Sci., 19 (Supplement 1): 9497

Donaldson, I. A. ,I.C.Hart and R. J. Heitzman, 1981. Growth hormone, insulin, prolactin and total thyroxine in the plasma of sheep implanted with the anabolic steroid trenbolone acetate alone or with oestradiol. Res. Vet. Sci. 30:7-12.

Drabkin, D. L. and Austin 1932. Spectrophotometric studies: Spectrophotometric constants for common hemoglobin derivatives in human, dog and rabbit blood. J. of Biological Chemistry, 719.

Duncan, D. B., 1955. Multiple ranges and multiple "F" test. Biometrics, 11: 1-12.

El-Ashry M.A. ,Afaf M. Fayed, K.M. Youssef, F.A. Salem and A. Aziz Hend, 2003. "Effect of feeding Flavomycin or yeast as feed supplement on lamb performance in Sinai" Egyptian J. Nutrition and feeds, 6: 1009-1022.

Eshratkhah, B., M. Sadaghian, S. Eshratkhah, S. Pourrabbi and K. Najafian, 2010a.Relationship between the blood thyroid hormones and lipid profile in Moghani sheep; influence of age and sex.Comp.Clin. Pathol., 19(1):15-20.

Eshratkhah, B., R. Beheshti, M. Reza Sabri, M. Sadaghina and S.M. Taj, 2010b.Variations of plasma thyroid hormones concentrations and their percentages during different ages of Sarabi calves. Global Veterinaria, 4 (4):357-361.

Estell, R.E. ;K.M. Havstad,; C.E. Heird,; E.L. Fredrickson; D.M.Hallford. and W.L. Shupe, 1993. Effects of repeated cycles of feed intake shifts on growth, feed efficiency and endocrine profiles of wither lambs. Small Ruminant Research, 10:103-118.

Fadel, A.M.A. and M.A. Rania Abusamra, 2007. Effects of supplemental yeast (Saccharomyces cerevisiae) culture on NDF digestibility and rumen fermentation of forage sorghum hay in Nubian goat's kids. Res. J. Agric. and Boil. Sci., (3): 133-137.

Fuller, R., 1989. Probiotics in man and animals. J. Appl.Bacteriol., 66: 365-378.

Gado, H.MO. , A.Z.M. Salem, P.H. Robinson, and M. Hassan, 2009. Influence of exogenous enzymes on nutrient digestibility, extent of ruminal fermentation as well as milk production 
and composition in dairy cows. Anim. Feed Sci. and Tech. 154:36-46.

Gupta, A.R.; R.C. Putra ; M. Sainin, and D. Swarup, 2007. Hematology and serum biochemistry of Chital (Axis axis) and Braking deer (Muntiacusmuntjak) reared in semi-captivity. Vet. Res. Commun., 31:801-808.

Huska, M., R. Link, G. Kovac, J. Bires and J. Lehocky, 2002.Stimulatory effect of Bacillus licheniformis in the prevention of diarrhea in calves.RocznikiNaukoweZootechniki (Supl, Z.) $15,181-186$

Hussein A.F., 2014. Effect of biological additives on growth indices and physiological responses of weaned Najdi ram lambs. J. Exp.. Biol. and Agric. Sci., 2(6):597-607.

Hussein M.F., A Gar-Elnabi, A.N. Aljarf ,R.S. Aljumaah, A.O. Bakhiet and M.A. Alshaikh, 2012. Variation of the Platelet indices of the dromedary camel (Camelusdromedarius) with age,sex and breed. African Journal of Biotechnology, 11(19): 4478-4483.

Ismaiel AM, AH. El-Far and II.Abou-Ganema, 2010. Effect of Tonilisat and Roemin W2 supplementations on the performance of lambs. International Scholarly and Scientific Research , Innovation 4: 11-29.

Jukna, C., V. Jukna and A. Simkus, 2003. The effect of some probiotic preparations on calves growth. Bulgar .J. Vet. Med., 6: 85-93.

Kadim, I. T., O. Mahgouba, and R. W. Purchasb, 2008.A review of the growth, and of the carcass and meat quality characteristics of the Onehumped camel (Camelus dromedaries). Meat Sci., 80: 555-569.

Kahl, S. and J. Bitman, 1983.Relation of plasma thyroxine and triiodothyronine to body weight in growth in growing male and female Holstein cattle. Journal of Dairy Science, 66:2386-2390.

Kahl, S., D. S.Lough,, T. S. Rumsey and M. B. Solomon, 1992. Effect of trenbolone acetate on hepatic 5'-deiodinase activity in growing ram and ewe lambs. J. Anim. Sci. 70(Suppl. 1):207 (Abstr. ).

Kearl, L.C., 1982. Nutrient Requirements of Ruminants in Developing Countries.Utah Agric. Exp. Station, Utah State University, Logan, USA. pp. 20-45.

Kee,H.J., E.W. Park and C.K. Lee, 2008. Characterization of beef transcripts correlated with tenderness and moisture. Mol. Cells, 25:428437.

Kikkawa, Y., T. Takada, Sutopo, K. Namikawa, H. Yonekawa and T. Amano, 2003. Phylogenies using mtDNA and SRY provide evidence for male-mediated introgression in Asian domestic cattle. Anim. Genet., 34:96-101.

KunavueN.and T. F. Lien, 2012. Effects of fulvic acid and probiotic on growth performance, nutrient digestibility, blood parameters and immunity of pigs. J. Anim. Sci. Adv., 2(8):711721.
Le Dividich, J. and B. Seve, 2000. Effects of underfeeding during the weaning period on growth metabolism and hormonal adjustments in piglets.Domes. Anim. Endoc.,19:63-74.

Mandour, M.A., S.A. Al-Shami, and G. Altabari, 2009. The effect of feeding probiotics on the productive performance of Saudi Arabia sheep breeds during fattening. Mansoura Vet. Med. J., XI (1):87-103.

Milewski, S. and P. Sobiech, 2009. Effect of dietary supplementation with saccharomyces cerevisiae dried yeast on milk yield, blood biochemical and haematological indices in ewe. Bull. Vet. InstPulawy, 53: 753-758.

Mirzadeh, KH., S. Tabatabaei, M. Bojarpour and M. Mamoei, 2010. Comparative study of hematological parameters according strain, age, sex, physiological status and season in Iranian cattle. J. Anim. Vet. Adv., 9(16):2123-2127.

Mohammed, A.K., G. Mohammed, and O.O. Akerejola, 2007. Hematological and serum biochemical changes in Bunaji work bulls after farmland ridging exercise in Kaduna State, Nigeria. J. Anim. Vet. Adv., 6:576-579.

Mohri, M., K. Shafiri and S. Eidi, 2007. Hematology and serum biochemistry of Holstein dairy calves: Age related changes and comparison with blood composition in adults. Res. Vet. Sci.,(83):30-39.

Musa, H.H., S.L. Wu, C.H. Zhu, H.I. Seri and G.Q. Zhu, 2009. The potential benefits of probiotics in animal production health. J. Anim.Vet. Adv., 8(2):313-321.

Newbold, C.J. 1995. Microbial feed additives for ruminants. Page 259-278 In: Biotechnology in Animal Feeds and Animal Feeding. R.J. Wallace and A. Chesson, eds. VCHverlagsgesellSchaftmbh, Weinheim, Germany.

Olayemi, F.O., D.O. Akinsku, E.O. Ojo and I.O. Azeez, 2006.Haematology of Kuri breed cattle. Folia Vet.,50:62-65.

Opara, M.N., N. Udevi, and I.C. Okoli, 2010.Haematological parameters and blood chemistry of apparently healthy west african dwarf (WAd) goats in owerri, south eastern Nigeria. New York Science Journal;3(8):68-72.

Riddell,J.B., A.J. Gallegos, D.L. Harmon, and K.R. McLeod, 2010. Addition of a Bacillus based probiotic to the diet of preruminant calves: Influence on growth, health, and blood parameters. Inter. J. Appl. Res. Vet. Med. 8, (1):78-85.

Saddiqi, H.A., M. Nisa, N. M.; Mukhtar, N.; M. A. Shahzad, M. A. A.; Jabbar, A. and M. Sarwar, 2011. Documentation of physiological parameters and blood profile in newly born Kajli lambs. Asian-Aust. J. Anim. Sci.,24, (7):912-918.

Salama A. M. A., S. A. Ibrahim, M.R.M. El-Mahdy, G.A. El-Sayaad and A.M. Shaarawy, 2005. Effect of some feed additives on feed intake, digestion coefficients, rumen parameters and economical efficiency of Friesian fattening 
calves. Egyptian J. Nutrition and feeds, 8 (1): 127-142.

Sarker, M. S. K., S. Y. Ko, S. M. Lee, G. M. Kim, J. K. Choi and C. J. Yang, 2010. Effect of different feed additives on growth performance and blood profiles of Korean Hanwoo calve J.Anim.Vet.Advan.,21:2754-2759.

SAS, 2003.SAS/STAT Procedures Guide for Personal Computer.

Sharma S. 1996. Studies on hormonal and blood biochemical profile of female buffalo calves as function of age. M.V.Sc. Thesis. Haryana Agriculture University.

Tambuwal, F.M; B.M. Agaie, and A. Bangana, 2002.Haematological and biochemical values of apparently healthy Red Sokoto goats. Proceeding of 27th Annual Conference, Nigerian Society of Animal production (NSAP), March, 17-21, FUTA, Akure, Nigeria. pp.50-53.

Thomas, J.W. ,M. Okamoto, W.C., Jacobson and L.A.Moore, 1994. A study of hemoglobin levels in the blood of young dairy calves and the alleviation of anemia by iron. Amer. Sci. Assoc. (91): 330-332.
Tibbo,M.; Y. Jibril,.; M. Woldemeskel,; F. Dawo,; K. Aragaw, and J.E.O. Rege, 2004. Factors affecting haematological profiles in three Ethiopian indigenous goat breeds. Inter. J. Appl. Res. Vet. Med., 2:297-309.

Titi H.H, R.O. Dmour and A.Y. Abdullah, 2008. Growth performance and carcass characteristics of Awassi lambs and Shami goat kid culture in their finishing diet. Animal Feed Science and Technology. 142: 33-43.

Todini, L., 2007. Thyroid hormones in small ruminants. Animal;1(7): 997-1008.

Whitley N.C, D. Cazac, B.J. Rude, D. JacksonO'Brien and S. Parveen, 2009. Use of commercial probiotics supplement in meat goat. J. Anim. Sci., 87: $723-728$

Wielgosz-Groth, Z. , M. Sobczuk-Szul, Z. Nogalski, C. Purwin , P. Pogorzelska-Przybyłek and R. Winarski, 2015. The Effect of gender and feeding system on the growth rate and blood parameters of Polish Holstein-Friesian $\mathrm{x}$ Limousin calves. Pak. Vet. J., 35(1): 33-37.

تأثير البروبيوتك على وزن الجسم والصفات الهيماتولوجية ومستويات هرموني الغدة الدرقية لحيران المغاتير المفطومة

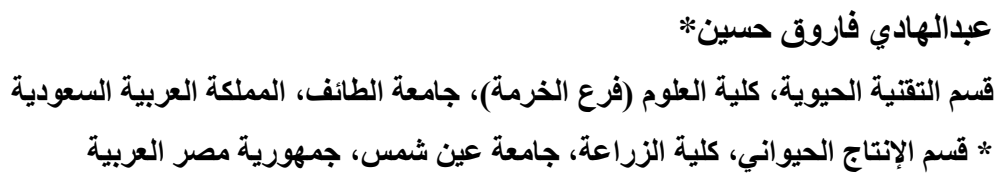

أجريت هذه الدراسة بهدف تقليل بعض التأثيرات السلبية التي تحدث نتيجة تعرض حيران الإبل للفطام المُبكر. حيث تم إستخدام

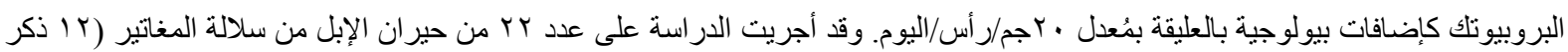

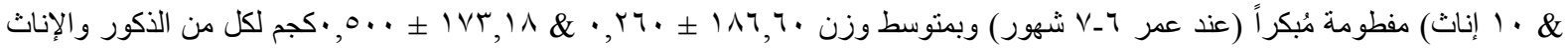
على التو الي ولمُدة ستة أثنهر تم خلالها تسجيل وزن الجسم و عمل صورة دم وتقدير مستوى هرموني الثيروكسين والتراي أيودوثيرونين في بلازما

الدم شهرياً. قُسمت الحيو انات في كل جنس إلى مجمو عتين متساويتين إحداهما تُمثل المجمو عة الضابطة بينما تُمثل الأخرى مجمو عة المُعاملة أوضحت النتائج أن للمُعاملة بالبروبيوتلك عند مستوى • r جم/ر أس/اليوم تأثيراً معنوياً (P>0.05) على وزن الجسم الحي ومُعدل الزيادة اليومية في كلا الجنسين ولكن كانت الذكور أكثر تفوقاً عن الإناث طوال فترة الدراسة،كما أظهرت النتائج أن حيو انات المجموعة المُعاملة بالبروبيوتلك تميزت بالقيم الأعلى معنوياً (P<0.05) في كل من تركيز هيموجلوبين الدم وكذلك العدد الكلي لخلايا الدم البيضاء مُقارنة بحيو انات المجموعة الضابطة

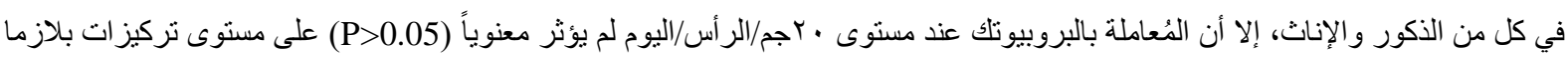
الدم من هرموني الغدة الدرقية في كلا الجنسين. بصرف النظر عن المُعاملة فقد كان للجنس نأثيراً معنوياً (P<0.05) على وزن الجسم والقياسات الهيماتولوجية ومستوى هرموني الغدة الدرقية في بلازما الدم حيث تميزت الذكور عن الإناث بالقيم الأعلى في وزن الجسم الحي و العدد الكلي لخلايا الدم البيضاء وكذلك تركيز بلازما الدم من هرموني الغدة الدرقية. بينما تميزت الإناث عن الذكور في قيم كل من تركيز هيموجلوبين الدم والهيماتوكريت و عدد خلايا الدم الحمر اء

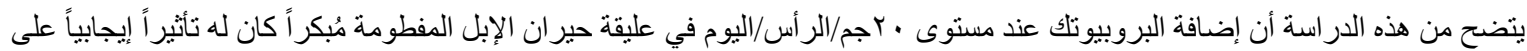
وزن الجسم وصورة الدم وبالتالي يكون هناك أداء إنتاجي جيد خلال فترة مابعد الفطام لتفادي الأثار السلبية التي من المُمكن حدوثها نتيجة صدمة 